BACKGRound: It has been shown that cells of the immune system release opioid peptides and possess receptors for them. The concentrations of opioid peptides in the peripheral circulation rapidly increase during inflammation and acute stress response.

Aims: The effect of opioid peptides Met-enkephalin (M-ENK) and beta-endorphin ( $\beta$-END) on the oxidative metabolism of normal human neutrophils and their death by apoptosis in vitro was investigated.

Methods: Isolated from peripheral blood, neutrophils were incubated in the presence or absence of $10^{-6}$ to $10^{-10} M$ of $M$-ENK and $\beta$-END for 12 and $18 \mathrm{~h}$. Apoptosis of neutrophils was determined in vitro by flow cytometric analysis of cellular DNA content and Annexin V-FITC protein binding to the cell surface. The MTT-reduction assay was employed to estimate the oxidative metabolism of neutrophils.

Results: Treatment with M-ENK caused a significant increase in apoptotic cells after $18 \mathrm{~h}$ of culture: *0 M (control) versus $10^{-10} \mathrm{M}, \boldsymbol{p} \leq 0.02 ;{ }^{* *} 10^{-10} \mathrm{M}$ versus $10^{-10} \mathrm{M}, \boldsymbol{p} \leq 0.02$. Treatment with $\beta$-END caused a significant increase in apoptotic cells after $12 \mathrm{~h}$ of culture: $0 \mathrm{M}$ versus $10^{-8} \mathrm{M}, \boldsymbol{p} \leq \mathbf{0 . 0 3}$; ${ }^{* *} 0 \mathrm{M}$ versus $10^{-10} \mathrm{M}, p \leq 0.04$. We found the significant increase in MTT reduction by neutrophils in the presence of M-ENK and $\beta$-END both before and after the culture. However, the ability of neutrophils to reduce the MTT salt to formazan decreased significantly after the culture.

Conclusions: We observed that the in vitro effect of opioid peptides on the neutrophil survival and their functional state was time and dose dependent. The presence of antioxidants in the culture medium modifies neutrophil survival.

Key words: Apoptosis, Opioid peptides, Human polymorphonuclear leukocytes (neutrophils), Reactive oxygen species

\section{Influence of opioid peptides on human neutrophil apoptosis and activation in vitro}

\author{
Zofia Sulowska ${ }^{1, C A}$, Ewa Majewska², \\ Katarzyna Krawczyk ${ }^{1}$, Magdalena Klink ${ }^{1}$ and \\ Henryk Tchórzewski ${ }^{1,3}$
}
${ }^{1}$ Microbiology and Virology Center, Polish Academy of Sciences, ${ }^{2}$ Department of Pathophysiology and Clinical Immunology, Military Medical Academy, ${ }^{3}$ Department of Clinical Immunology, Polish Mother's Memorial Institute, Lodz, Poland

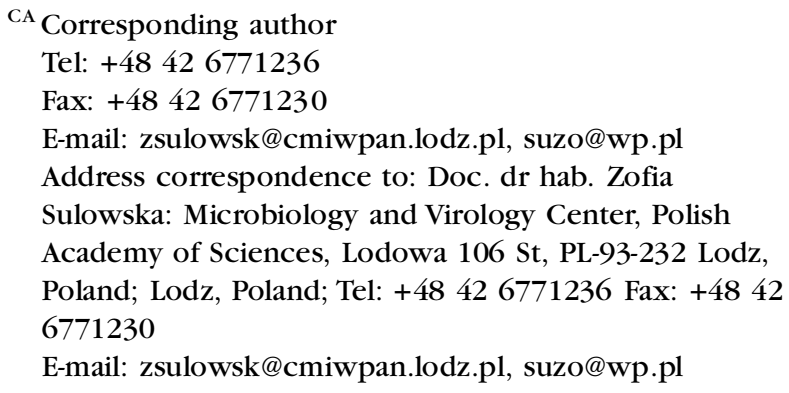

consisting of five amino acids Tyr-Gly-Gly-Phe-Met or Leu that are responsible for their biological activity. They differ in molecular size. Met-enkephalin (M-ENK) is a pentapeptide, and beta-endorphin $\left(\beta\right.$-END) is composed of 31 amino acids. ${ }^{8}$ Stress response and inflammation are associated with the release of high levels of opioid peptides into systemic circulation. $^{\text {? }}$

Polymorphonuclear neutrophils (PMNs) are involved in the response to invasion of the host by bacteria, viruses and fungi. The production of reactive oxygen species (ROS), including superoxide anion $\left(\mathrm{O}_{2}^{-}\right)$and hydrogen peroxide $\left(\mathrm{H}_{2} \mathrm{O}_{2}\right)$ and nitric oxide, is considered to play a key role in the host defense against invading microorganisms, but can also be responsible for tissue damage. ${ }^{10,11}$ To respond to the tissue inflammation, the neutrophils migrate into the inflamed site where they are exposed to the 
numerous environmental signals such as soluble substances including cytokines, opioid peptides.

Apoptosis, also called programmed cell death, plays a critical role in the resolution of inflammation and in the regulation of the host immune response. Normal human neutrophils spontaneously undergo apoptosis in vitro and in vivo. Apoptosis of the activated neutrophils has been suggested as an important mechanism for their removal from inflammatory sites. ${ }^{12,13}$ The modulation of this process is very important for maintaining the balance between defense and injury. There is evidence suggesting that oxidative stress plays a pivotal role in the induction of apoptosis in neutrophils. ${ }^{14-17}$ It has been shown that opioid peptides, such as M-ENK or $\beta$-END, like inflammatory cytokines, may prime neutrophils to enhanced response after subsequent challenge with specific activation. ${ }^{18,19}$ So, opioid peptides like many others agents that prime or activate human neutrophils can affect, or not, spontaneous neutrophil apoptosis in vitro.

The aim of the present study was to evaluate the possibility of whether ROS released by neutrophils as a consequence of the activation with opioid peptides may promote their own death by apoptosis. The neutrophil apoptosis as an in vitro model to investigate the effect of exogenous opioid peptides on the neutrophil survival was used.

\section{Materials and methods}

\section{Reagents}

M-ENK, $\beta$-END, naloxone, trypan blue, propidium iodide (PI), 3-(4,5-diethylthiazol-2-yl)2,5-diphenyltetrazolium bromide (MTT), phorbol 12-myristate 13-acetate (PMA), superoxide dismutase (SOD), catalase (CAT), fetal calf serum (FCS), $100 \mathrm{U} / \mathrm{ml}$ of penicillin and $100 \mu \mathrm{g} / \mathrm{ml}$ of streptomycin, ethylenediamine tetraacetate (EDTA), Ribonuclease A (RNase A), and tumor necrosis factor-alpha (TNF- $\alpha$ ) were obtained from Sigma (Sigma Chemical Co., St Louis, MO, USA). Phosphate-buffered saline (PBS) and RPMI 1640 were purchased from Biomed (Lublin, Poland). Gradisol G (specific gravity, $1.115 \mathrm{~g} / \mathrm{ml}$ ) was obtained from Polfa (Kutno, Poland). The Annexin V/FITC Kit was purchased from Bender MedSystems Diagnostics GmbH (Vienna, Austria). Twenty-four-well or 96-well flat-bottom plates were from NUNC Brand Products (Roskilde, Denmark). May-Grünwald-Giemza dyes were purchased from AQUA-MED (Lodz, Poland). Izopropanol (2-propanol) was obtained from $\mathrm{POCH}$ (Gliwice, Poland).

\section{Cell preparation}

PMN (neutrophils) were isolated from heparinized peripheral blood collected from healthy donors using a one-step density-gradient centrifugation on Gradisol $G$ at $400 \times \mathrm{g}$ at room temperature for $30 \mathrm{~min}$. The residual erythrocytes were removed from the cell population by hypotonic lysis. The neutrophils were washed twice and resuspended in PBS. ${ }^{20}$ The cell suspensions were stored in PBS at a concentration of $1 \times 10^{6}$ or $2 \times 10^{6} / \mathrm{ml}$ at $4^{\circ} \mathrm{C}$ and used within $2 \mathrm{~h}$. Cell purity $(>98 \%)$ and viability (>98\%) were determined by May-Grünwald-Giemsa staining of cytocentrifuged samples and by Trypan blue exclusion, respectively.

Informed consent was obtained from all donors. The Local Ethical Committee accepted this study.

\section{Culture conditions of normal human neutrophils}

Neutrophils were maintained in RPMI 1640 supplemented with 10\% FCS and antibiotics (100 U of penicillin and $100 \mu \mathrm{g} / \mathrm{ml}$ of streptomycin). Either $2 \mathrm{ml}$ or $200 \mu 1$ of cell suspension $\left(1 \times 10^{6} / \mathrm{ml}\right)$ were placed in 24-well or 96-well plates, respectively, and duplicate and triplicate conditions were cultured in humidified atmosphere at $37^{\circ} \mathrm{C}$ with $5 \% \quad \mathrm{CO}_{2}$ for varying periods of time as indicated. Neutrophil suspensions were incubated in the absence (control cell samples) or presence of $10^{-6}$ to $10^{-10} \mathrm{M}$ of M-ENK and $\beta$-END for 12 and $18 \mathrm{~h}$, and next washed once in PBS. Aliquots were removed and used in assays of neutrophil apoptosis and MTT reduction.

\section{MTT-reduction assay}

As a positive control of the activation-induced model of a process referred to as oxidative burst, marked by $\mathrm{H}_{2} \mathrm{O}_{2}$ and $\mathrm{O}_{2}{ }^{-}$production, the cells treated with PMA and TNF- $\alpha$ were used. The potency of PMN to produce ROS was measured as their ability to reduce the tetrazolium salt MTT to formazan by a colorimetric method as previously described. ${ }^{21}$ Briefly, neutrophils $\left(2 \times 10^{5} /\right.$ well $)$ were placed in 96 -well plates in $150 \mu 1$ of RPMI 1640 with $10 \%$ of FCS and PMA (100 ng/ml), TNF- $_{\alpha}(10 \mathrm{ng} / \mathrm{ml})$, or tested opioid peptides at concentrations as indicated, in triplicate, respectively. Then, $50 \mu 1$ of MTT solution in PBS $(1 \mathrm{mg} / \mathrm{ml})$ was added to each well. In experiments with cultured neutrophils at the end of the culture period, the MTT solution was added to each well. The plates were centrifuged at $1000 \mathrm{rpm}$ for $1 \mathrm{~min}$ and incubated for $1 \mathrm{~h}$ at $37^{\circ} \mathrm{C}$ and $5 \% \mathrm{CO}_{2}$. The plates were then centrifuged for $15 \mathrm{~min}$ at $2000 \mathrm{rpm}$, and the supernatants were removed by rapid inversion. Formazan produced by PMN in each well was dissolved in $100 \mu 1$ of 2-propanol. An enzyme-linked immunosorbent assay reader (Multiskan MS, Helsinki, Finland) measured optical densities at dual wavelengths (540 and $620 \mathrm{~nm}$ ). 
A. ANNEXIN V BINDING ASSAY

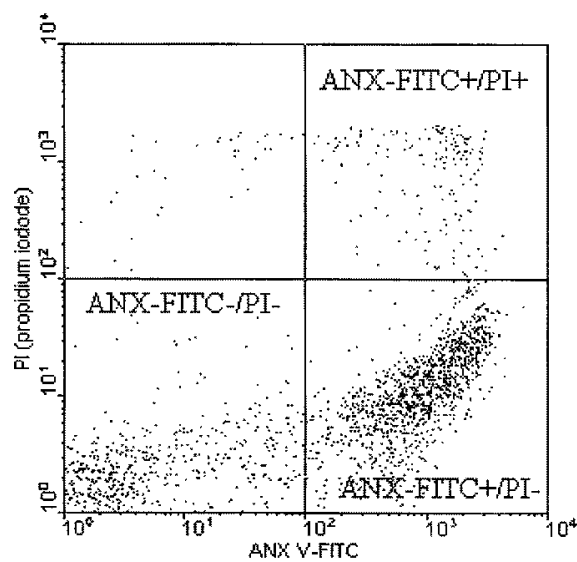

B. CELLULAR DNA CONTENT

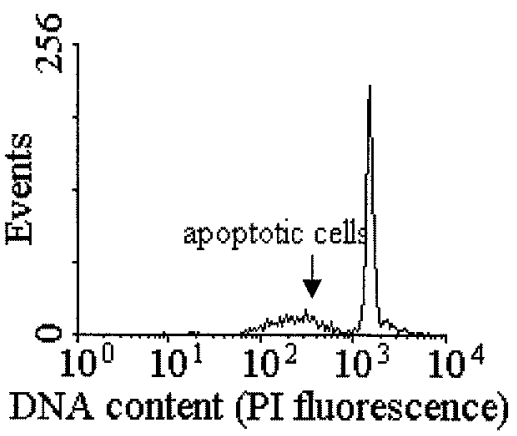

FIG. 1. An example of the quantitation of apoptosis using flow cytometry. (A) Typical dot plot diagram of ANX-FITC/PI flow cytometry of cells undergoing apoptosis. The lower left quadrant shows the viable cells, which exclude PI and are negatives for ANX-FITC binding. The lower right quadrant represents the early apoptotic cells, ANX-FITC positive and PI negative, demonstrating cytoplasmic membrane integrity. The upper right quadrant contains the non-viable, necrotic or late apoptotic cells, positive for ANX-FITC binding and for PI uptake. The data are presented as the sum of percentage of cells located in the lower right and the upper right quadrants. (B) Histogram of cells analyzed for PI fluorescence (DNA content). The histogram shows the appearance of the apoptotic region (indicated by arrow) for cells undergoing apoptosis.

\section{Detection of PMN apoptosis by flow cytometry}

Measurement of fluorescein isothiocyanate-labeled Annexin $V$ binding to the cell surface

The major change associated with the cell during the early phases of apoptosis is the loss of membrane phospholipid asymmetry. This event leads to the translocation of phosphatidylserine (PS) from the inner side of the cell membrane to the outer membrane. ${ }^{22,23}$ Cells expressing PS at the plasma membrane bind fluorescein isothiocyanate-labeled Annexin V (ANX-FITC), and cells with compromised membrane incorporate and bind PI to the cellular DNA (Fig. 1A). ${ }^{24}$ The percentage of apoptotic neutrophils was determined using the binding of ANXFITC protein to the cell surface according to the manufacturer's specification. Specific binding of ANXFITC was performed by incubation of the cell suspension $\left(1 \times 10^{5}\right.$ cells) in $100 \mu 1$ of binding buffer with $2 \mu 1$ of ANX-FITC and $10 \mu 1$ of PI (final concentration, $1 \mu \mathrm{g}$ ) for $25 \mathrm{~min}$ in the dark at room temperature. After incubation, the cells were centrifuged and analyzed using a FACScan flow cytometer (Becton Dickinson, Heidelberg, Germany) equipped with Cell Quest software for cell acquisition and data analysis.

\section{Analysis of DNA content by PI staining and flow cytometry}

DNA content was analyzed by flow cytometry PI staining as previously described by Nicoletti et al. ${ }^{25}$ with a slight modification. ${ }^{26}$ The method is based on the fact that endonuclease activation leads to generating low molecular weight DNA (LMW-DNA) fragments during apoptosis. After membrane perme- abilization LMW-DNA leaks out, resulting in decreased DNA content in apoptotic cells, while the DNA content in non-apoptotic cells remains unchanged.

Briefly, the PMN $\left(10^{6} / 200 \mu \mathrm{l}\right)$ after washing with PBS supplemented with $0.5 \mathrm{mM}$ EDTA were resuspended in ice-cold $70 \%$ ethanol and stored at $-20^{\circ} \mathrm{C}$ for 1-2 days. Then, neutrophils were treated with RNase A $(10 \mu \mathrm{g} / \mathrm{ml})$ and stained with $20 \mu \mathrm{g} / \mathrm{ml}$ of PI. Cells were held in the dark at room temperature for $15 \mathrm{~min}$ and then stored at $4^{\circ} \mathrm{C}$ until flow cytometric analysis. The fluorescence of individual nuclei was measured using Cell Quest software for cell acquisition and data analysis. The percentage of apoptotic cell nuclei (located as a hypodiploid DNA peak in the DNA fluorescence histogram) was calculated (Fig. 1B).

\section{Statistical analysis}

The results are expressed as the mean \pm standard deviation (SD) of at least five independent experiments. Evaluation of statistical significance was performed by Wilcoxon's signed rank test. $p \leq 0.05$ was considered significant.

\section{Results}

The significant increase in MTT reduction by neutrophils in the presence of M-ENK and $\beta$-END was observed both before and after the culture. That reflects directly the degree of stimulation induced by M-ENK and $\beta$-END. However, the ability of neutrophils to reduce the MTT salt to formazan decreased significantly after the culture (Table 1 ). $\mathrm{TNF}_{-} \alpha$ and PMA were used as the potent receptor-dependent and 
Table 1. The effect of opioid peptides on MTT reduction in vitro

\begin{tabular}{|c|c|c|c|c|c|}
\hline \multirow[t]{2}{*}{ Stimulator } & \multicolumn{2}{|c|}{ Time of culture } & \multirow[t]{2}{*}{ Stimulator } & \multicolumn{2}{|c|}{ Time of culture } \\
\hline & $1 \mathrm{~h}$ & $18 \mathrm{~h}$ & & $1 \mathrm{~h}$ & $18 \mathrm{~h}$ \\
\hline Control & $0.44 \pm 0.29$ & $0.11 \pm 0.09$ & Control & $0.49 \pm 0.27$ & $0.14 \pm 0.10$ \\
\hline M-ENK, $10^{-6} \mathrm{M}$ & $0.49 \pm 0.29 *$ & $0.11 \pm 0.10$ & B-END, $10^{-6} \mathrm{M}$ & $0.53 \pm 0.29 *$ & $0.14 \pm 0.10$ \\
\hline M-ENK, $10^{-8} \mathrm{M}$ & $0.48 \pm 0.28^{*}$ & $0.11 \pm 0.10$ & $\mathrm{~B}-\mathrm{END}, 10^{-8} \mathrm{M}$ & $0.54 \pm 0.29 *$ & $0.14 \pm 0.11$ \\
\hline TNF- $\alpha, 10 \mathrm{ng} / \mathrm{ml}$ & $0.55 \pm 0.24^{*}$ & $0.11 \pm 0.10$ & TNF- $\alpha, 10 \mathrm{ng} / \mathrm{ml}$ & $0.60 \pm 0.23^{*}$ & $0.12 \pm 0.10$ \\
\hline $\mathrm{PMA}, 100 \mathrm{ng} / \mathrm{ml}$ & $0.62 \pm 0.18^{*}$ & $0.09 \pm 0.01$ & $\mathrm{PMA}, 100 \mathrm{ng} / \mathrm{ml}$ & $0.62 \pm 0.18^{*}$ & $0.09 \pm 0.01$ \\
\hline
\end{tabular}

The data are given as the mean \pm SD of optical density as described in Materials and methods. ${ }^{*}$ Statistical significance, $p \leq 0.05$ versus control at time 0 .

receptor-independent stimulators of the oxidative burst of neutrophils. Figure 2A,B shows a representative experiment in which $10^{-6} \mathrm{M}$ of opioid peptides has been used. The data are given as the mean and SD of optical densities at 540 and $620 \mathrm{~nm}$ for separate experiments. Incubation of neutrophils together with M-ENK, $\beta$-END and opioid-receptor antagonist naloxone $\left(10^{-6} \mathrm{M} / \mathrm{ml}\right)$ did not reveal any differences in their effect on MTT reduction. MTT reduction by neutrophils stimulated with M-ENK was $0.416 \pm 0.294$
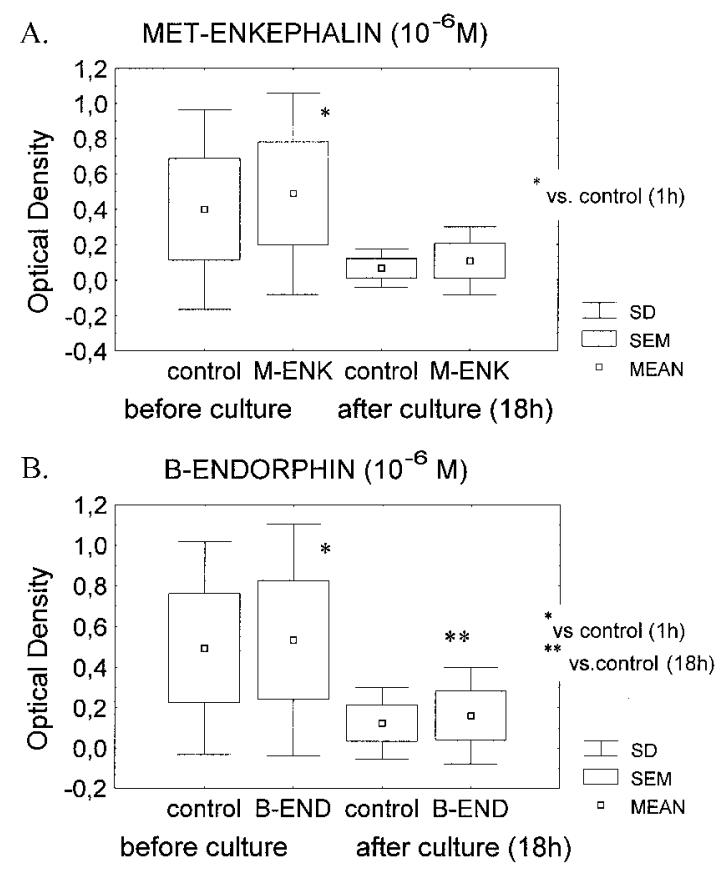

FIG. 2. A representative experiment of MTT reduction by neutrophils treated with $10^{-6} \mathrm{M}$ of opioid peptides before and after culturing in vitro. The potency of PMN to produce ROS as their ability to reduce the tetrazolium salt MTT to formazan was measured as described in Materials and methods. Briefly, neutrophils $\left(2 \times 10^{5} /\right.$ well) were placed in 96-well plates in $150 \mu$ l of RPMI 1640 with $10 \%$ of FCS and M-ENK and/or $\beta$-END $\left(10^{-6} \mathrm{M}\right)$. Then, $50 \mu$ l of MTT solution in PBS $(1 \mathrm{mg} / \mathrm{ml})$ was added to each well. In experiments with cultured neutrophils at the end of the culture period, the MTT solution was added to each well. The plates were centrifuged at $1000 \mathrm{rpm}$ for $1 \mathrm{~min}$ and incubated for $1 \mathrm{~h}$ at $37^{\circ} \mathrm{C}$ and $5 \%$ $\mathrm{CO}_{2}$. Formazan produced by PMN in each well was dissolved in $100 \mu \mathrm{l}$ of 2-propanol. The data are presented as the mean and SD of optical densities. versus $0.414 \pm 0.282$ and with $\beta$-END was $0.345 \pm$ 0.271 versus $0.346 \pm 0.260$ in the presence or not of naloxone, respectively. Naloxone administered alone had no effect on MTT reduction. Figure 1A,B illustrates the method of neutrophil apoptosis detection and evaluation. The percentage of apoptotic PMN in culture treated with M-ENK and $\beta$-END evaluated by flow cytometry is presented in Table 2 . The effects of M-ENK and $\beta$-END on neutrophil apoptosis were dependent on the time of culture and doses of opioids used. Treatment of the neutrophils with M-ENK caused a significant increase in the cells binding ANXFITC and PI after $18 \mathrm{~h}$ of culture, while the treatment with $\beta$-END caused a significant increase in apoptotic cells after $12 \mathrm{~h}$ of culture. The data are presented as the mean of the percentage of the sum of cells binding Annexin V (ANX-FITC+/PI- and ANX-FITC+/ $\mathrm{PI}+$ ), as shown in Fig. 1A.

To evaluate the possibility that ROS released from neutrophils stimulated with opioid peptides may promote the death of PMN by apoptosis, the effect of exogenous antioxidants such as SOD and CAT on neutrophil survival in vitro was investigated. As a positive control of the activation-induced model of neutrophil apoptosis, the cells treated with PMA were used. PMA is a receptor-independent stimulator of a nicotinamide adenine dinucleotide phosphate oxidase that activates neutrophils to release a high amount of $\mathrm{H}_{2} \mathrm{O}_{2}$ and $\mathrm{O}_{2}{ }^{-}$and lead to subsequent cell death. As presented in Table 3, the presence of SOD $(300 \mathrm{U} / \mathrm{ml})$ and CAT $(1200 \mathrm{U} / \mathrm{ml})$ in the culture media markedly inhibited the spontaneous neutrophil apoptosis. However, catalase did not modify the PMAinduced apoptosis. We observed that the percent inhibition of M-ENK-treated neutrophil apoptosis by SOD was significantly lower compared with nontreated neutrophil: $42 \%, 44 \%$ and $54 \%$, respectively. This effect was most apparent when apoptosis was measured using flow cytometric analysis of DNA content. CAT resulted in $48 \%$ inhibition of spontaneous apoptosis and this effect was significantly attenuated in the presence of $\beta$-END $\left(10^{-10} \mathrm{M}\right)$. However, no significant differences in the inhibition of apoptosis by SOD and CAT between untreated and 
Table 2. The effect of opioid peptides on spontaneous neutrophil apoptosis in vitro measured by ANX-FITC and PI binding

\begin{tabular}{|c|c|c|c|c|c|}
\hline \multirow[t]{2}{*}{ M-ENK stimulator } & \multicolumn{2}{|c|}{ Time of culture } & \multirow[t]{2}{*}{$\beta^{-E N D}$ stimulator } & \multicolumn{2}{|c|}{ Time of culture } \\
\hline & $12 \mathrm{~h}$ & $18 \mathrm{~h}$ & & $12 \mathrm{~h}$ & $18 \mathrm{~h}$ \\
\hline $\begin{array}{l}0 \mathrm{M} \\
10^{-6} \mathrm{M} \\
10^{-8} \mathrm{M} \\
10^{-10} \mathrm{M}\end{array}$ & $\begin{array}{l}63.2 \pm 12.4 \\
66.8 \pm 17.7 \\
67.6 \pm 14.8 \\
64.1 \pm 19.3\end{array}$ & $\begin{array}{l}68.2 \pm 14.7 \\
79.0 \pm 10.7^{*} \\
70.4 \pm 16.0 \\
73.0 \pm 11.9^{* *}\end{array}$ & $\begin{array}{l}0 \mathrm{M} \\
10^{-6} \mathrm{M} \\
10^{-8} \mathrm{M} \\
10^{-10} \mathrm{M}\end{array}$ & $\begin{array}{l}59.7 \pm 11.6 \\
68.7 \pm 12.0 \\
71.3 \pm 7.6 \dagger \\
70.2 \pm 11.8 \dagger \dagger\end{array}$ & $\begin{aligned} 68.2 & \pm 14.8 \\
72.4 & \pm 8.8 \\
69 & \pm 15.9 \\
70 & \pm 18.0\end{aligned}$ \\
\hline
\end{tabular}

Data are presented as mean \pm SD of the percentage of the sum of $A N X+/ P I-$ and ANX-FITC+/PI+ cells for nine separate experiments. Treatment of cells with M-ENK caused a significant increase in apoptotic cells after $18 \mathrm{~h}$ of culture: ${ }^{*} 0 \mathrm{M}$ (control) versus $10^{-6} \mathrm{M}, p \leq 0.02 ;{ }^{*} 10^{-6} \mathrm{M}$ versus $10^{-10} \mathrm{M}, p \leq 0.02$. Treatment with $\beta^{-E N D}$ caused a significant increase in apoptotic cells after $12 \mathrm{~h}$ of culture: $† 0 \mathrm{M}$ versus $10^{-8} \mathrm{M}, p \leq 0.03 ; \dagger+0 \mathrm{M}$ versus $10^{-10} \mathrm{M}, p \leq 0.04$.

opioid peptide-treated neutrophils were found when apoptosis was measured using ANX-FITC/PI binding.

\section{Discussion}

PMN have a limited life span in vivo and in vitro, and the various mediators can initiate the apoptosis process in these cells. PMN can recognize the opioid peptides via different classes of classical type of opioid receptor ${ }^{27}$ or by a non-opiate-specific receptor. $^{8,29}$ The life span and functional activity of mature PMN can be extended and modified in vivo and in vitro by numerous agents such as pro-inflammatory cytokines, including granulocyte-colony stimulating factor, interleukin-1, interleukin-8, lipopolysaccharide, and $\mathrm{TNF}_{-} \alpha{ }^{26,30-34}$ The results presented here indicate that the opioid peptides, like other inflammatory mediators present at sites of inflammation, may modulate the survival of neutrophils. An association between ROS released from neutrophils and the lifetime of neutrophils, which is thought to be connected with induction of the apoptosis process was observed. ${ }^{14,15,35}$ It was also demonstrated that the presence of ROS, released from primed and/or activated neutrophils, accelerates the apoptosis of neutrophils themselves since the exogenous anti- oxidants added to the culture medium significantly prolonged neutrophil survival. ${ }^{16,17}$ Narayanan et al. ${ }^{36}$ suggested that neutrophil apoptosis is in part related to the ability of a cell to maintain an appropriate oxidant-antioxidant balance. Haberstock et al. ${ }^{19,37}$ demonstrated that M-ENK-induced the $\mathrm{O}_{2}{ }^{-}$release from human neutrophils in dose-dependent fashion. The authors concluded that M-ENK-induced $\mathrm{O}_{2}{ }^{-}$ release was associated with diacylglycerol and the protein-kinase $C$ signal transduction pathway. The priming phenomenon is referred to as a process wherein the response of neutrophils to an activating stimulus is enhanced considerably by pre-exposure of cells to the priming agent. ${ }^{38}$ Some authors suggest that most neutrophil priming agents delay apoptosis and hence increase the survival of neutrophils at the inflamed site ${ }^{34,39}$ Pasnik et al. ${ }^{18}$ and Haberstock and Marotti ${ }^{19}$ have shown that M-ENK and $\beta$-END in physiological concentration were involved in neutrophil priming that resulted in the significant upregulation of chemiluminescence of neutrophil stimulated with fMLP in vitro. This might suggest the delay of neutrophil apoptosis in the presence of opioid peptides. The MTT-reduction assay is one of the tests with which it is possible to assess the oxidative burst ability of PMN. Because of the chemical resemblance,

Table 3. Inhibition of spontaneous and opioid peptide-mediated neutrophil apoptosis by exogenous SOD and CAT

\begin{tabular}{|c|c|c|c|c|}
\hline \multirow[t]{3}{*}{ Apoptosis assay } & \multicolumn{4}{|c|}{$\%$ Inhibition } \\
\hline & \multicolumn{2}{|c|}{$\mathrm{ANX}+/ \mathrm{PI}-$ and $\mathrm{ANX}+/ \mathrm{PI}+$ cells } & \multicolumn{2}{|c|}{ DNA content } \\
\hline & SOD & CAT & SOD & CAT \\
\hline $\begin{array}{l}\text { Medium alone } \\
\text { M-ENK, } 10^{-8} \mathrm{M} \\
\text { M-ENK, } 10^{-10} \mathrm{M} \\
\beta^{-E N D, ~} 10^{-8} \mathrm{M} \\
\beta^{-E N D, 10} 10^{-10} \mathrm{M} \\
\text { PMA, } 100 \mathrm{ng} / \mathrm{ml}\end{array}$ & $\begin{array}{l}41.0 \pm 12 \\
38.2 \pm 16 \\
48.4 \pm 14 \\
45.0 \pm 9.0 \\
41.4 \pm 16 \\
58.2 \pm 11\end{array}$ & $\begin{array}{c}32.2 \pm 7.5 \\
30.0 \pm 10 \\
23.5 \pm 13 \\
34.5 \pm 19 \\
34.5 \pm 19 \\
\text { nd }\end{array}$ & $\begin{array}{l}54.8 \pm 19 \\
42.6 \pm 18^{*} \\
44.8 \pm 13^{*} \\
53.0 \pm 6 \\
44.0 \pm 10 \\
51.4 \pm 18\end{array}$ & $\begin{array}{l}48.2 \pm 9 \\
39.8 \pm 19 \\
45.4 \pm 18 \\
50.2 \pm 14 \\
38.2 \pm 6^{* *} \\
\text { nd }\end{array}$ \\
\hline
\end{tabular}

Opioid peptide-treated and non-treated neutrophils $\left(1 \times 10^{6} / \mathrm{ml} /\right.$ well $)$ were cultured at $37^{\circ} \mathrm{C}$ in the presence of SOD $(300 \mathrm{U} / \mathrm{ml})$ or CAT (1200 U $\left./ \mathrm{ml}\right)$ and apoptosis was measured $18 \mathrm{~h}$ later by flow cytometry, as described in Materials and methods. Results are presented as the mean \pm SD of five separate experiments. \% Inhibition of spontaneous and opioid peptide-mediated apoptosis was calculated as: (1 - \% apoptosis in SODtreated or CAT-treated neutrophils / \% apoptosis in control neutrophils) $\times 100$. ${ }^{*} p \leq 0.05,{ }^{*} p \leq 0.05$ compared with medium alone. nd, Not determined. 
the mechanism of MTT reduction is similar to that of nitroblue tetrazolium. ${ }^{40}$ We found the significant increase in MTT reduction by neutrophils in the presence of M-ENK and $\beta$-END both before and after the culture. It is plausible that the decreased MTT reduction observed after $18 \mathrm{~h}$ of the culture was caused by a progressive increase in the number of cells showing the characteristics of apoptotic cells. These results are consistent with the literature data showing that neutrophil apoptosis is closely associated with its functional impairment. ${ }^{41}$ Since PMN progressively became apoptotic during the culture in the presence of M-ENK and $\beta$-END, we wondered whether the effect described was a result of an activation of the apoptotic process in these cells by opioid peptides via ROS released from activated neutrophils. To verify this hypothesis, we examined the effect of SOD and CAT added to the culture medium on the course of neutrophil apoptosis occurring in the presence of opioid peptides. The fact that SOD and CAT protected neutrophils against opioid peptide-induced apoptosis suggests that ROS may partly be involved in its induction. The present results show that opioid peptides can regulate neutrophil functions via apoptosis and thus may limit the inflammatory response.

ACKNOWLEDGEMENTS. This study was supported by a grant 4 P05A 05614 from the State Committee for Scientific Research (KBN), Poland.

\section{References}

1. Weigent DA, Blalock JE. Associations between the neuroendocrine and immune systems. J Leukoc Biol 1995; 58: 137-150.

2. Weigent DA, Blalock JE. Production of peptide hormones and neurotransmitters by the immune system. Chem Immunol 1997; 69: 1-30.

3. Igaz P, Toth S, Falus A. Interplay between the immune and neuroendocrine systems. Med Sci Monit 1998; 4: 728-733.

4. Przewlocki R, Hassan AH, Lason W, Epplen C, Herz A, Stein C. Gene expression and localization of opioid peptides in immune cells of inflamed tissue: functional role in antinociception. Neuroscience 1992 ; 48: 491-500.

5. Vindrola O, Padros MR, Sterin-Prync A, Ase A, Finkielman S, Nahmod V. Proenkephalin system in human polymorphonuclear cells. Production and release of a novel $1.0-\mathrm{kD}$ peptide derived from synenkephalin. $J$ Clin Invest 1990; 86: 531-537.

6. Blalock JE. Production of peptide hormones and neurotransmitters by the immune system. Chem Immunol 1992; 52: 1-24.

7. Harbour DV, Galin FS, Hughes TH, Smith EM, Blalock JE. Role of leukocyte-derived pro-opiomelanocortin peptides in endotoxic shock. Circ Shock 1991; 35:181-191.

8. Panerai AE, Sacerdote P. $\beta$-endorphin in the immune system: a role at last? Immunol Today 1997; 18: 317-319.

9. Imura H, Fukata J. Endocrine-paracrine interaction in communication between the immune and endocrine systems. Activation of the hypothalamic-pituitary-adrenal axis in inflammation. Eur J Endocrinol 1994; 130: 32-37.

10. Miller RA, Britigan BE. The formation and biologic significance of phagocyte-derived oxidants. J Invest Med 1995; 43: 39-49.

11. Babior BM. The respiratory burst of phagocytes. J Clin Invest 1984; 73 : 599-601

12. Savill JS, Wyllie AH, Henson JE, Walport MJ, Henson PM, Haslett C. Macrophage phagocytosis of aging neutrophils in inflammation. Programmed cell death in the neutrophil leads to its recognition by macrophages. J Clin Invest 1989; 83: 865-875.

13. Savill J. Apoptosis in resolution of inflammation. J Leukoc Biol 1997; 61: 375-380

14. Buttke TM, Sandstrom PA. Oxidative stress as a mediator of apoptosis. Immunol Today 1994; 15: 7-10.

15. Kasahara Y, Iwai K, Yachie A, et al. Involvement of reactive oxygen intermediates in spontaneous and CD95 (Fas/Apo-1)-mediated apoptosis of neutrophils. Blood 1997; 89: 1748-1753.
16. Oishi K, Machida K. Inhibition of neutrophil apoptosis by antioxidants in culture medium. Scand J Immunol 1997; 45: 21-27.

17. Rollet-Labelle E, Grange MJ, Elbim C, Marquetty C, Gourgerot-Pocidalo MA, Pasquier C. Hydroxyradical as potential intracellular mediator of polymorphonuclear neutrophil apoptosis. Free Radic Biol Med 1998; 24: $563-572$.

18. Pasnik J, Tchórzewski H, Baj Z, Luciak M, Tchórzewski M. Priming effect

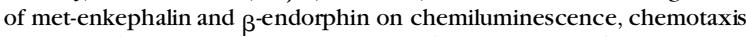
and $\mathrm{CD} 11 \mathrm{~b}$ molecule expression on human neutrophils in vitro. Immunol Lett 1999; 67: 77-83.

19. Haberstock H, Marotti T. Methionine-enkephalin primes human neutrophils for enhancement superoxide anion production. Immunopharmacol Immunotoxicol 1997; 19: 135-145.

20. Zeman K, Tchorzewski H, Majewska E, Pokoca L, Pinkowski R. A simple and rapid method of the simultaneous isolation of highly purified lymphocytes and neutrophils from peripheral blood. Immunol Pol 1988; XIII: $217-224$

21. Oez S, Platzer E, Welte K. A quantitative colorimetric method to evaluate the functional state of human polymorphonuclear leukocytes. Blut 1990; 60: $97-102$.

22. Darzynkiewicz Z, Bruno S, Del Bino G, et al. Features of apoptotic cells measured by flow cytometry. Cytometry 1992; 13: 795-806.

23. Fadok VA, Voelker DR, Campbell PA, Cohen JJ, Bratton DL, Henson PM. Exposure of phosphatidylserine on the surface of apoptotic lymphocytes triggers specific recognition and removal by macrophages. J Immunol 1992; 148: 2207-2216.

24. Varmes I, Haanen C, Steffens-Nakken H, Reutelingsperger C. A novel assay for apoptosis. Flow cytometric detection phosphatidylserine expression on early apoptotic cells using fluorescein labelled Annexin V. I Immunol Methods 1995; 184: 39-51.

25. Nicoletti I, Migliorati G, Oagliacci MC, Grignani F, Riccardi C. A rapid and simple method for measuring thymocyte apoptosis by propidium iodide staining and flow cytometry. I Immunol Methods 1991; 139: 271-279.

26. Kettritz R, Gaido ML, Haller H, Luft FC, Jennette CJ, Falk RJ. Interleukin8 delays spontaneous and tumor necrosis factor- $\alpha$-mediated apoptosis of human neutrophils. Kidney Int 1998; 53: 84-91.

27. Makman MH, Bilfinger TV, Stefano GB. Human granulocytes contain an opiate alkaloid-selective receptor mediating inhibition of cytokineinduced activation and chemotaxis. $J$ Immunol 1995; 154 1323-1330.

28. Hazum E, Chang KI, Cuatrecasas P. Specific nonopiate receptor for $\beta$-endorphin. Science 1979; 205: 1033-1035.

29. Sharp BM, Tsukayama DT, Gekker G, Keane WF, Peterson PK. Betaendorphin stimulates human polymorphonuclear leukocyte superoxide production via a stereoselective opiate receptor. J Pharmacol Exp Ther 1987; 242: 579-582

30. Cox G. Glucocrticoid treatment inhibits apoptosis in human neutrophils Separation of survival and activation outcomes. J Immunol 1995; 154: 4719-4725.

31. Liles WC, Dale DC, Klebanoff SJ. Gluocorticoids inhibit apoptosis of human neutrophils. Blood 1995; 86: 3181-3188.

32. Cox G, Austin RC. Dexamethasone-induced suppression of apoptosis in human neutrophils requires continuous stimulation of new protein synthesis. J Leukoc Biol 1997; 61: 224-230.

33. Colotta F, Re F, Polentarutti N, Sozzani S, Mantowani A. Modulation of granulocytes and programmed cell death by cytokines and bacterial products. Blood 1992; 80: 2012-2020.

34. Murray J, Barbara JAJ, Lopez AF, et al. Regulation of neutrophil apoptosis by tumor necrosis factor- $\alpha$ : requirement for TNFR 55 and TNFR75 for induction of apoptosis in vitro. Blood 1997; 90: 2772-2783.

35. Lundqvist-Gustafsson $\mathrm{H}$, Bengtsson $\mathrm{T}$. Activation of the granule pool of the NADPH oxidase accelerates apoptosis in human neutrophils. $J$ Leukoc Biol 1999; 65: 196-204.

36. Narayanan PK, Ragheb K, Lawler G, Robinson JP. Defects in intracellular oxidative metabolism of neutrophils undergoing apoptosis. J Leukoc Biol 1997; 61: 481-488.

37. Haberstock H, MarottiT, Banfic H. Neutrophil signal transduction in Metenkephalin modulated superoxide anion release. Neuropeptides 1996 ; 30: $193-201$.

38. Hallet MB, Lloyds D. Neutrophil priming: the cellular signals that say 'amber' but not 'green'. Immunol Today 1995; 16: 264-268.

39. Condliffe AM, Kitchen E, Chilvers ER. Neutrophil priming: pathophysiological consequences and underlying mechanisms. Clin Science 1998; 94: 461-471.

40. Oez S, Welte K, Platzer E, Kalden JR. A simple assay for quantifying the inducible adherence of neutrophils. Immunobiology 1990; 180: $308-315$.

41. Whyte MKB, Meagher LC, MacDermont J, Haslett C. Impairment of function in aging neutrophils is associated with apoptosis. J Immunol 1993; 150: 5124-5134.

Received 15 April 2002

Accepted 6 May 2002 


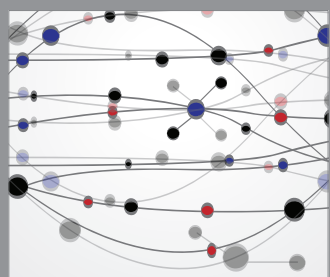

The Scientific World Journal
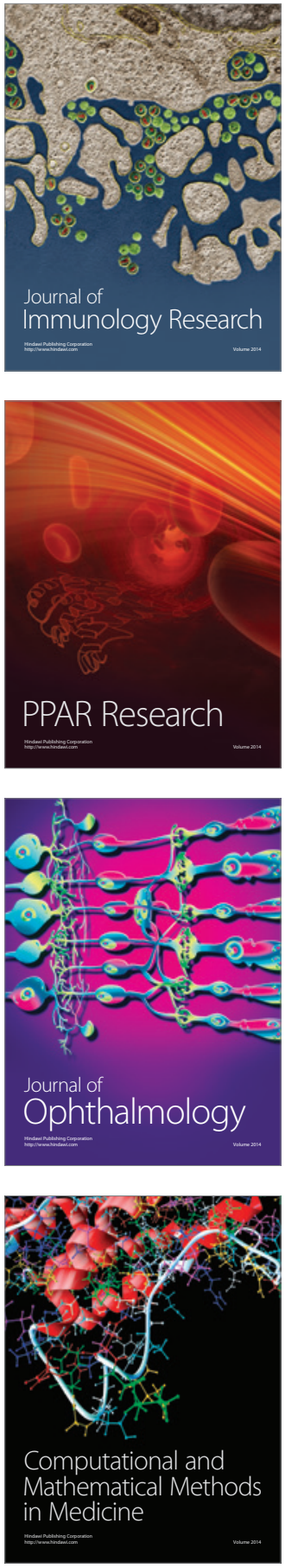

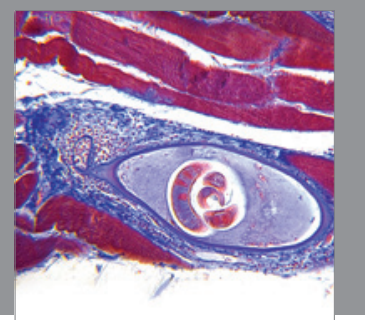

Gastroenterology

Research and Practice
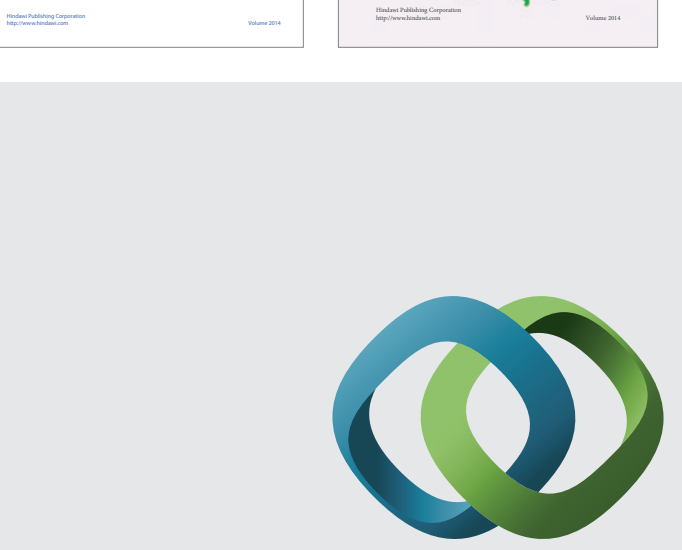

\section{Hindawi}

Submit your manuscripts at

http://www.hindawi.com
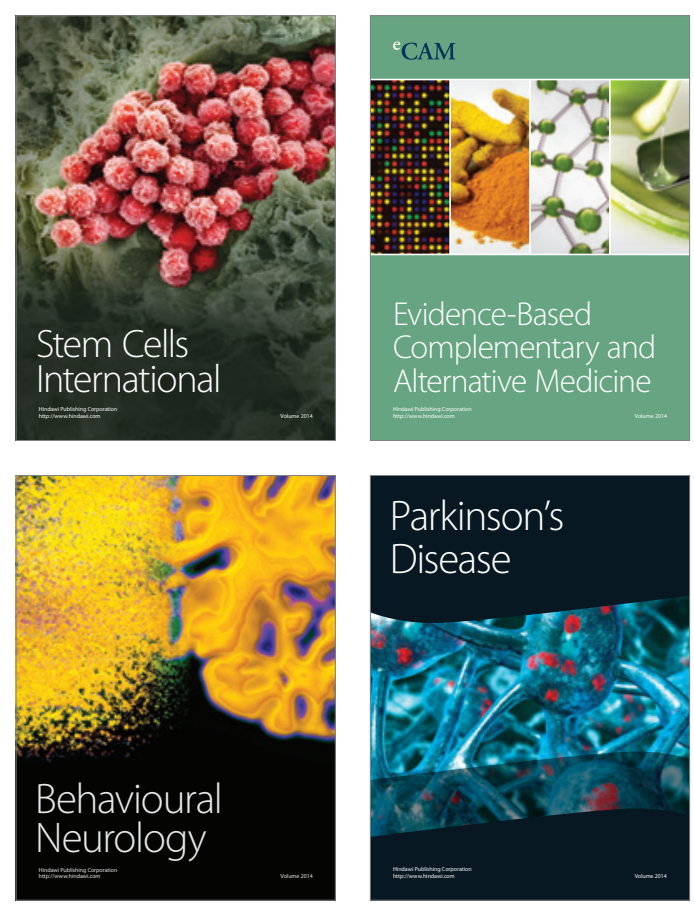

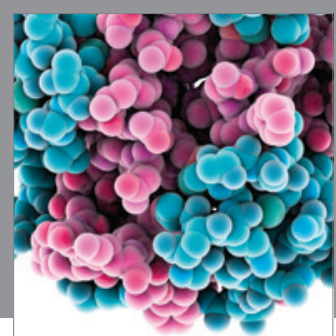

Journal of
Diabetes Research

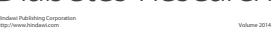

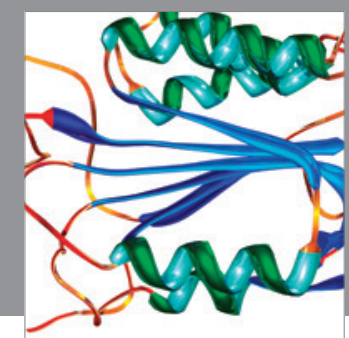

Disease Markers
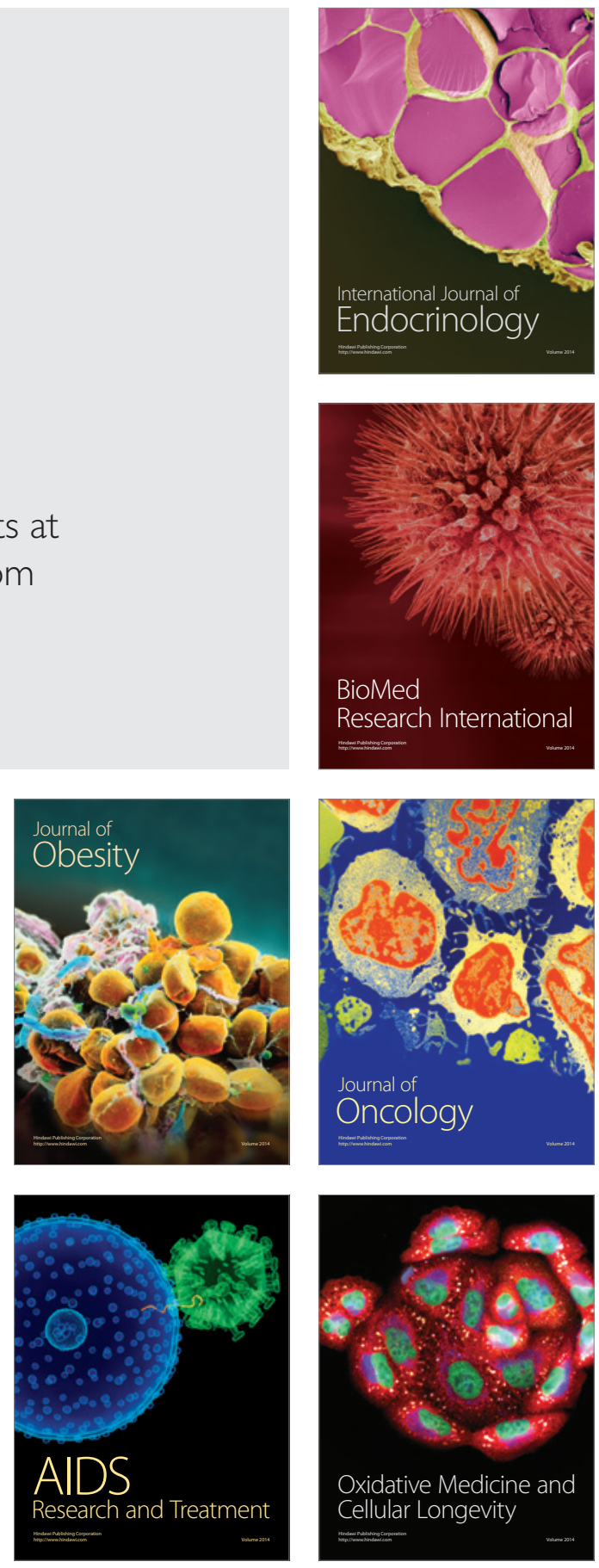